DOI https://doi.org/10.30525/978-9934-588-91-4-37

\title{
ЛЕГІТИМАЦІЯ ВЛАДИ В ДЕМОКРАТИЧНИХ ПОЛІТИЧНИХ СИСТЕМАХ ТА ПРОБЛЕМА КРИЗИ ЛЕГІТИМАЦЇ̈
}

\author{
Оніщенко А. В. \\ аспірантка кафедри політології філософського факультету \\ Київського національного університету імені Тараса Шевченка \\ м. Київ, Україна
}

Найважливішим критерієм для вимірювання успішності в публічній політиці $є$ рейтинг. Проте, з кожним роком він $є$ все менш стабільним і все тяжче дається його утримання. Сьогодні не рідкісними $\epsilon$ ситуації різкої втрати політиком свого рейтингу (та рівня підтримки та довіри виборців) невдовзі після виборів.

Яскравим прикладом прояву цієї тенденції в Україні може послужити падіння рейтингу провладної партії «Слуга народу», яка від рейтингу 43,16\% [1] на парламентських виборах 2019 року знизились до 15,5\% [6] на місцевих виборах 2020 року. Ми також можемо говорити i про пропорційне падіння рейтингу Президента Володимира Зеленського, який після перемоги на виборах Президента України 3 2019 року з результатом у $73,22 \%$ [2] знизився до $29 \%$ станом на 6 вересня 2020 [4].

Відповідно, при такій різкій втраті довіри з боку громадян, не може бути й мови про ефективність діяльності політика, адже він стикається 3 перепонами у вигляді суспільної критики, посилення опозиції, актів громадянської непокори та іншими формам спротиву. В свою чергу, подібна ситуація негативно позначається на державі в цілому і $\epsilon$ особливо небезпечною в умовах ведення війни на Сході країни.

Все вищезазначене дозволяє нам говорити про актуалізацію даної проблематики дослідження в рамкам сучасної політичної науки. Особливо гостро питання легітимності постає для країн $з$ демократичними політичними режимами, де передача влади та обмеження частини природних прав людьми здійснюється добровільно. Так, у працях «батьків» доктрини політичної легітимності, Жан-Жака Руссо «Про суспільну угоду, або Принципи політичного права» [5], Джона Локка «Два трактати про правління» [8] та Томаса Гоббса «Левіафан» [7], центральне місце посідала ідея «суспільного договору» як способу порятунку від первинного хаосу та анархії за рахунок встановлення політичного порядку та обміну людиною частини власних природних прав на захист з боку держави. Що ж саме ми маємо на увазі під суспільним договором? Суспільний договір - це неявна згода між 
членами суспільства щодо співпраці та допомоги один одному. Таке визначення дає нам Оксфордський словник [9].

Саме за демократії легітимація політичної влади народом $\epsilon$ обов'язковою умовою ефективного функціонування держави. Якщо ж цього не відбувається, ми можемо говорити про кризу легітимності, що означає зниження реальної підтримки органів державної влади, правлячого режиму, їі політичного лідера, яке впливає на якісні зміни їх ролей і функцій.

Криза легітимності не є рідкісним явищем. Ця проблема особливо гостро постає для країн в яких відбуваються активні трансформаційні процеси. Сьогодні в більшості країн світу ми можемо зіткнутись 3 існуванням в масовій свідомості негативного сприйняття образу політичної влади та політичного лідера. Саме ця тенденція спричинила активізацію включення у політику людей інших сфер.

Викликом для забезпечення легітимності є також активізація процесів глобалізації, що провокує появу нових форм легітимації та легітимації з одночасним зникненням легітимації як окремого явища, їі об'єднання 3 іншими соціологічними концепціями. Сьогодні держава стикається 3 все більшою кількістю нових викликів, яким вона не в змозі протидіяти. Саме подібна слабкість в питанні захисту громадян та їх інтересів і підриває рівень довіри до державної влади [3].

Серед основних чинників зниження рівня довіри до влади: рішень;

- надмірна централізація та закритість процесу прийняття

- високий рівень корупції;

- низька ефективність управління;

- тощо [3].

Отже, все вищезгадане говорить про необхідність поглибленого наукового дослідження проблеми легітимації влади та розробки практичних рекомендацій, що будуть направлені на створення нової моделі взаємодії між владою та громадянським суспільством, яка дозволить їм вийти на якісно новий рівень взаєморозуміння та довіри. Актуальність даної теми полягає в необхідності вивчення якісно нового способу легітимації та його значення для подолання кризи легітимності та процесі здобуття політичної влади новим типом політичних лідерівхаризматів. У випадку України, проявом значення публічної легітимації в процесі здобуття політичної влади можемо назвати президентські вибори та вибори до Верховної Ради України 2019 року. Саме тому, розробка даної теми необхідна для пояснення особливостей даного феномену та прогнозування можливих змін в політичній системі України пов'язаних з приходом нової політичної еліти. 


\section{Література:}

1. Вибори народних депутатів України 2019 - Офіційний сайт Центральної виборчої комісії [Електронний ресурс]. - Режим доступу: https://www.cvk.gov.ua/pls/vnd2019/wp300pt001f01=919.html

2. Вибори Президента України 2019 - Офіційний сайт Центральної виборчої комісії [Електронний ресурс]. - Режим доступу: https://www.cvk.gov.ua/pls/vp2019/wp300pt001 f01=720.html

3. Коваль О.Я. Легітимність державної влади: співвідношення правових і моральних аспектів реалізації. - Львівський державний університет внутрішніх справ, - Львів, 2018. - 230 с.

4. Президентський рейтинг Зеленського за літо обвалився на чверть Новинний портал ВBC News [Електронний ресурс]. - Режим доступу: https://www.bbc.com/ukrainian/news-54176005

5. Руссо Ж.-Ж. Про суспільну угоду, або Принципи політичного права. / Укр. пер. $з$ фр. та ком. О. Хома. - Київ: Port-Royal, 2001. - 349 с.

6. Як Зеленський втрачає великі міста на місцевих виборах Новинний портал BBC News [Електронний ресурс]. - Режим доступу: https://www.bbc.com/ukrainian/features-54373163

7. Гоббс.Т. Левиафан, или материя форма и власть государства церковного и гражданского. Сочинения : в 2 т. Т. 2. - М. : Мысль, 1991. - Т. 2. - С. 95.

8. Локк Д. Два трактата о правлении. Сочинения : в 3 т. Т. 3. - М. : Мысль, 1988. - Т. 3. - С. 317.

9. Social contract [Електронний pecypc]. - Режим доступу : http://oxforddictionaries.com/definition/english/social-contract 